\title{
Bauhaus at the zoo
}

\author{
Modernist designers in the 1930s found inspiration in the life sciences.
}

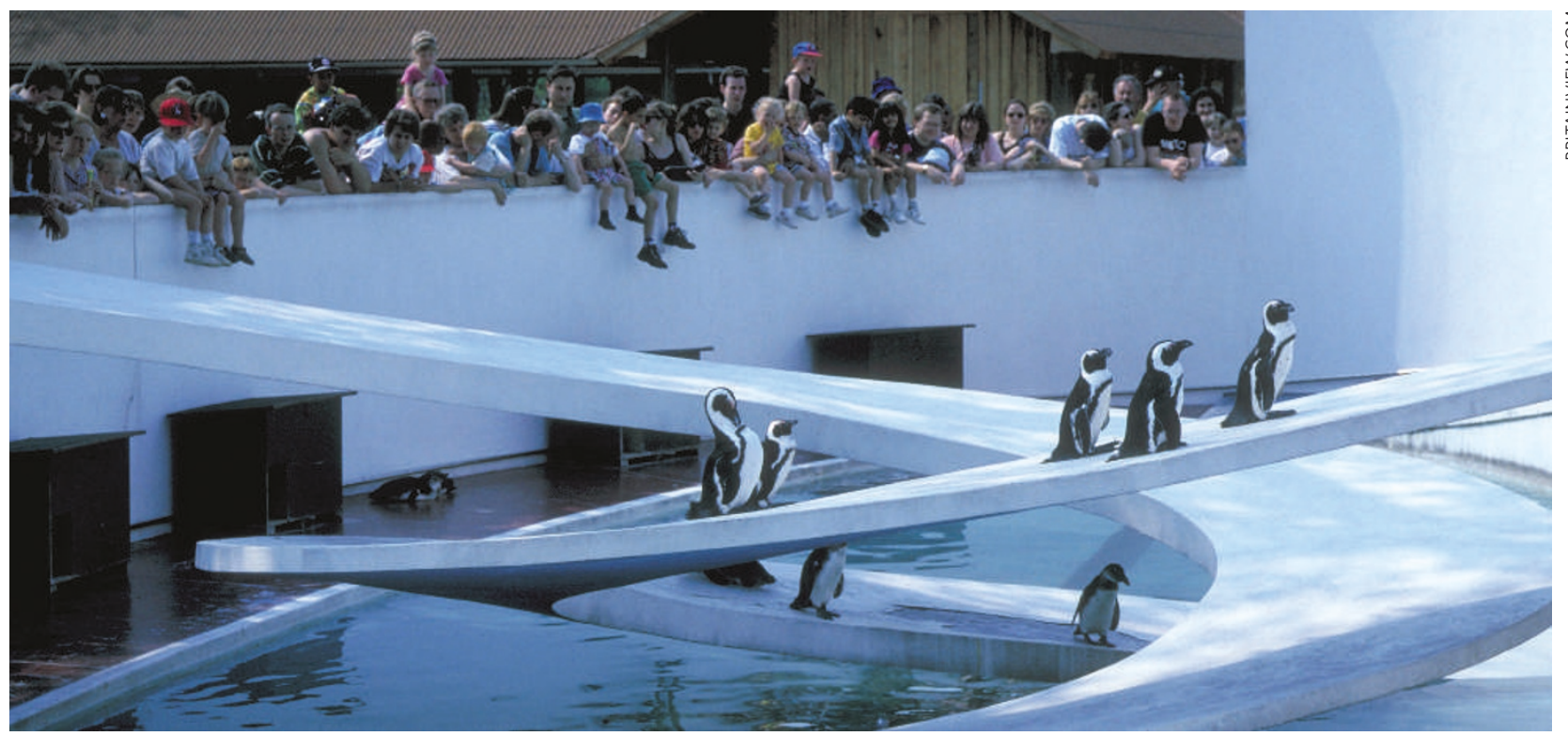

The penguin pool at London Zoo was built in the Bauhaus style to show how animals can thrive in novel environments.

\section{Peder Anker}

In the mid 1930s, faculty members from the Bauhaus design school in Germany fled Nazi harassment and moved to London. Among them were the school's former director, Walter Gropius, and the head of its metal workshop, László Moholy-Nagy, whose art will be on display next month at the Tate Modern in London. The radical designers, who sought to unify arts and crafts with industrial universalism, found new allies and patrons in a community of biologists in London who adapted Bauhaus architecture and art as part of their scientific vision for the future.

One of these was the ecologist Julian Huxley. As secretary of the Zoological Society of London he had an apartment at the zoo, which he used partly as a showroom for modernist design. Here, scientists, artists, architects, environmentalists and the science-fiction writer $\mathrm{H}$. G. Wells regularly met for discussions about how to save humankind from environmental, economic and social destruction.

Bauhaus design was one of the group's chief passions, and Gropius looked to Huxley and his friends with hope and admiration. Traditional architecture and design reinforced an unfortunate dualism between people and nature, Huxley believed, whereas the Bauhaus approach promised a harmonious reunion. To Huxley, nothing less than the evolutionary survival of the human species was at stake.

The zoo became the testing ground for these architectural ideas. The zoologist Solly Zuckerman believed that the difference between humans and animals was "almost certainly one of degree only", and he saw the life of primates as "a crude picture of a social level from which emerged our earliest human ancestors".

Visitors to the zoo could observe their own primitive desires in animals, Zuckerman argued, so it was of moral importance to place the animals in a model home for healthy living. The gorilla house and the penguin pool, along with a series of other buildings, were therefore built in the Bauhaus style.

But it was also politically important to the group to display thriving animals such as penguins in a highly unnatural setting, to show that humans too could prosper in new environments. "The most unlikely animals seem to thrive under what would seem the most unnatural conditions," zoologist Peter Chalmers Mitchell observed, if they have "freedom from enemies, regular food and general hygiene". The same would hold for workers and the poor, who desperately needed to be liberated from their 'natural' condition of criminal and filthy slums.

Moholy-Nagy, meanwhile, had found a major source of inspiration in Raoul Francé, a biologist and author who argued that humans should learn to copy nature's own inventions. Francé founded the science of bionics to pursue this end, calling it 'bio-technique'. Moholy-Nagy followed suit and told designers to use nature as a "constructional model" and to look for "prototypes in nature" to determine functional design. He read the work of Huxley and his friends and used it to generate his own principles, techniques and processes that could be applied to human design.

Moholy-Nagy's 1935 film In the Cradle of the Deep documents the growth of lobsters and the fisherman's struggle to search them out. He argued that a "prehistoric animal shell is constructed in such a wonderful way that we could immediately adapt it to a fine bakelite or other moulded plastic form". The point of the film was to show designers that observing the life of animals can teach us about how form follows function.

His investigations into architecture and photography were also informed by the life sciences. He defined architecture "as an organic component of living" and argued that "architecture will be brought to its fullest realization only when the deepest knowledge of human life in the biological whole is available."

It was while living in London that MoholyNagy revolutionized the art of photography by capturing forces of life in action. By taking snapshots (as opposed to posed photos), he sought to replace static classical art with dynamic images of active people. $\mathrm{He}$ also tried to highlight the activity of places and objects. He used light and shade in a photograph of a laboratory tube, for example, to evoke a sense of gas moving within the glass pipe.

His artwork can be seen alongside that of fellow modernist Josef Albers in the exhibition "Albers and Moholy-Nagy: From the Bauhaus to the New World" at Tate Modern in London from 9 March to 4 June. Peder Anker is a research fellow in history at the University of Oslo, 0315 Oslo, Norway. 